\title{
Manual Count
}

National Cancer Institute

\section{Source}

National Cancer Institute. Manual Count. NCI Thesaurus. Code C154795.

A technique to determine the number of entities, which is performed by visual inspection. 